\title{
ベバシズマブの抗腫瘍効果に及ぼす レニンーアンジオテンシン系抑制薬の影響
}

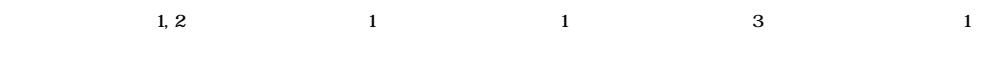
京都大学医学部附属病院薬斉部 ${ }^{1}$, 社会保隃京都病院薬斉部 ${ }^{2}$ 京都大学医学部附属病院外来化学療法部 ${ }^{3}$

\section{Influence of Renin-Angiotensin System Blockers on Anti-Cancer Effect of Bevacizumab}

\author{
Fumiaki Kitazawa ${ }^{1,2}$, Tomohiro Terada ${ }^{1}$, Kazushige Takahashi ${ }^{1}$, \\ Shigemi Matsumoto ${ }^{3}$ and Ken-ichi Inui ${ }^{* 1}$ \\ Department of Pharmacy, Kyoto University Hospital, Faculty of Medicine, Kyoto University ${ }^{1}$ \\ Department of Pharmacy, Social Insurance Kyoto Hospital ${ }^{2}$ \\ Outpatient Oncology Unit, Kyoto University Hospital, Faculty of Medicine, Kyoto University ${ }^{3}$
}

\author{
$\left[\begin{array}{l}\text { Received December 22, } 2008 \\ \text { Accepted March 2, } 2009\end{array}\right]$
}

The aim of this study was to clarify the influence of renin-angiotensin (RA) system blockers on the anti-cancer effect of chemotherapy with bevacizumab and its adverse effects. Twenty-six patients treated for metastatic colorectal cancer at Kyoto University Hospital between A ugust 2007 and July 2008 were assessed. All of the patients received bevacizumab plus mFOLFOX 6 or FOLFIRI, and were divided into a control group (23 patients) and an RA system blocker group ( 3 pa tients).

Regarding background factors, which included chemotherapy doses, the only significant difference between the groups was with respect to age. However, hypertension grades in the RA system blocker group were significantly higher than those in the control group, and RA system blockers had no significant antihypertensive effect. There was no severe proteinuria in either group. A s for anti-cancer effects, in the control group, 6 patients exhibited a partial response and in 16 patients, the disease was stable. In only one patient was the disease progressive. On the other hand, the disease was progressive in all patients in the RA system blocker group.

These findings indicate that anti-hypertensive agents which provide better hypertension control than RA system blockers may be necessary as first line medication for the management of bevacizumab-induced hypertension. Although RA system blockers are useful antihypertension agents, they might not be able to control bevacizumab-induced hypertension and proteinuria, and could reduce the anti-cancer effect of bevacizumab.

Key words - bevacizumab, renin-angiotensin system blockers, anti-cancer effect, mFOLFOX 6, FOLFIRI, hypertension

\section{緒言}

ベバシズマブは, 血管内皮増殖因子(以下, VEGF と 略す)をターゲットとし, 腫瘍の血管新生を阻害する新 規分子標的薬剂である. 炎の作用特性から，従来の抗が ん剂との併用療法で相乗効果が期待され, 実際, ベバシ ズマブは転移性大腸がんにおいて FOLFOX やFOLFIRI と併用することによって生存期間のさらなる延長をもた らした12).

VEGF は腫瘍の進展および抵抗性獲得における中心的 役割を果たし，关の作用も多彩である. 血管新生以外に
も，血管透過性亢進 ${ }^{3)}$, リンパ管新生 ${ }^{4)}$ ，抗アポトーシス 作用 ${ }^{5)}$, 抗腫瘍免疫応答の亢進 ${ }^{6}$ などが知られている.生 理学的にも重要とされる血管新生には, 一酸化窒素(以 下,NO と略す)がVEGF から血管新生に至る細胞内シ グナル伝達経路に光の伝達物質として密接に関連してい $ろ^{78)}$. NO は平滑筋弛緩作用や抗動脈硬化作用を有し， 血管緊張や血小板凝集を調節する薬理学的に最も重要な 因子の一つである9 . 兴のため, VEGF を阻害するべバ シズマブの抗血管新生作用には，下流にあるNO 合成経 路が阻害され，NO が減少することが一部関与してい る ${ }^{10)}$. また，NO の減少は血圧の上昇を惹起することか ら，高血圧がベバシズマブの特徵的な副作用でもあり， 
蛋白尿なども多く発現する ${ }^{11,12)}$.

現在 これらの副作用を制御する目的として，レニンー アンジオテンシン(以下, RA と略す)系抑制薬の使用 が，降圧作用の機序と尿蛋白の改善作用の点から推奨さ れている ${ }^{13-15)}$. また，循環器疾患において RA 系抑制薬 は汎用薬であり，ベバシズマブを用いた化学療法による 治療前から服用している患者も数多い.RA 系抑制薬 は, ブラジキニンの効果増強作用およびアンジオテンシ ンタイプ 2 受容体の間接的活性化によって , NO の産生 を元進する ${ }^{10,16)}$. すなわち, ベバシズマブの薬理作用と 相反するものであり(図 1), RA 系抑制薬はベバシズマ ブの効果を減弱させる可能性が考えられる.しかし，RA 系抑制薬とベバシズマブの併用に関する基礎的および臨 床的検討はほとんど実施されておらず，併用療法の副作 用や抗腫瘍効果に及ぼす影響は明らかにされていない．

光こで, 本研究ではベバシズマブを併用した mFOLFOX 6 療法およびFOLFIRI 療法を対象に, ベバシズマ ブが惹起する高血圧および蛋白尿の発現状況と RA 系抑 制薬による副作用のマネジメントについて検討した．ま た，RA 系抑制薬がベバシズマブの抗腫瘍効果に影響を 及ぼすか否かを検討した。

方法

\section{1. 対象患者}

京都大学医学部附属病院ではベバシズマブが平成 19 年 8 月 1 日に採用された . 乥こで, 本研究の調査期間は 平成 19 年 8 月から平成 20 年 7 月までの 1 年間とし，光 の期間内にベバシズマブを併用した mFOLFOX 6 療法あ るいはFOLFIRI 療法を施行された患者 32 症例を解析対
象とした . 全症例のうち, 3症例は調査終了前に治療が 開始され，評価できないことから除外した．また別の3 症例は治療後，いずれも 2 コースでオキサリプラチンに 起因する過敏症が発現し，レジメンが変更されたことか ら本解析から除外した．したがって，対象はこれら 6 症 例を除いた全 26 症例とした。また，RA 系抑制薬を服 用していた群を投与群，服用していなかった群を非投与 群とし この 2 群間で副作用や効果の比較解析を行った .

\section{2. 治療レジメン}

ベバシズマブを併用する mFOLFOX 6 療法は , ベバシ ズマブ : $5 \mathrm{mg} / \mathrm{kg}$, オキサリプラチン : $85 \mathrm{mg} / \mathrm{m}^{2}$, レボ ホリナートカルシウム $: 200 \mathrm{mg} / \mathrm{m}^{2}$, フルオロウラシ ル : 急速静注 $400 \mathrm{mg} / \mathrm{m}^{2}$ および持続静注 $2,400 \mathrm{mg} / \mathrm{m}^{2}$ が 2 週ごとに投与される方法である . 同樣に , ベバシズマ ブ併用 FOLFIRI 療法は, mFOLFOX 6 療法におけるオキ サリプラチンをイリノテカン : $120 \mathrm{mg} / \mathrm{m}^{2}$ に置き換えた レジメンである . また , 施行された投与量の比較は , 光

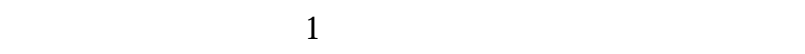
することにより行った．なお，MFOLFOX 6あるいは FOLFIRI の投与量は, 乥れ光れの標準投与量に対する施 行投与量の割合(\%)で表した .

\section{3. 副作用の重症度および抗腫瘍効果の評価}

ベバシズマブの副作用である高血圧および蛋白尿に関 する重症度については, 医師が Common Terminology Criteria for Adverse Events v 3.0 (CTCAE v 3.0)に従って 評価した . 副作用の解析は治療期間中の最も高い Grade を評価することで行った．また，ベバシズマブによる抗 腫瘍効果は, Response Evaluation Criteria in Solid Tumors

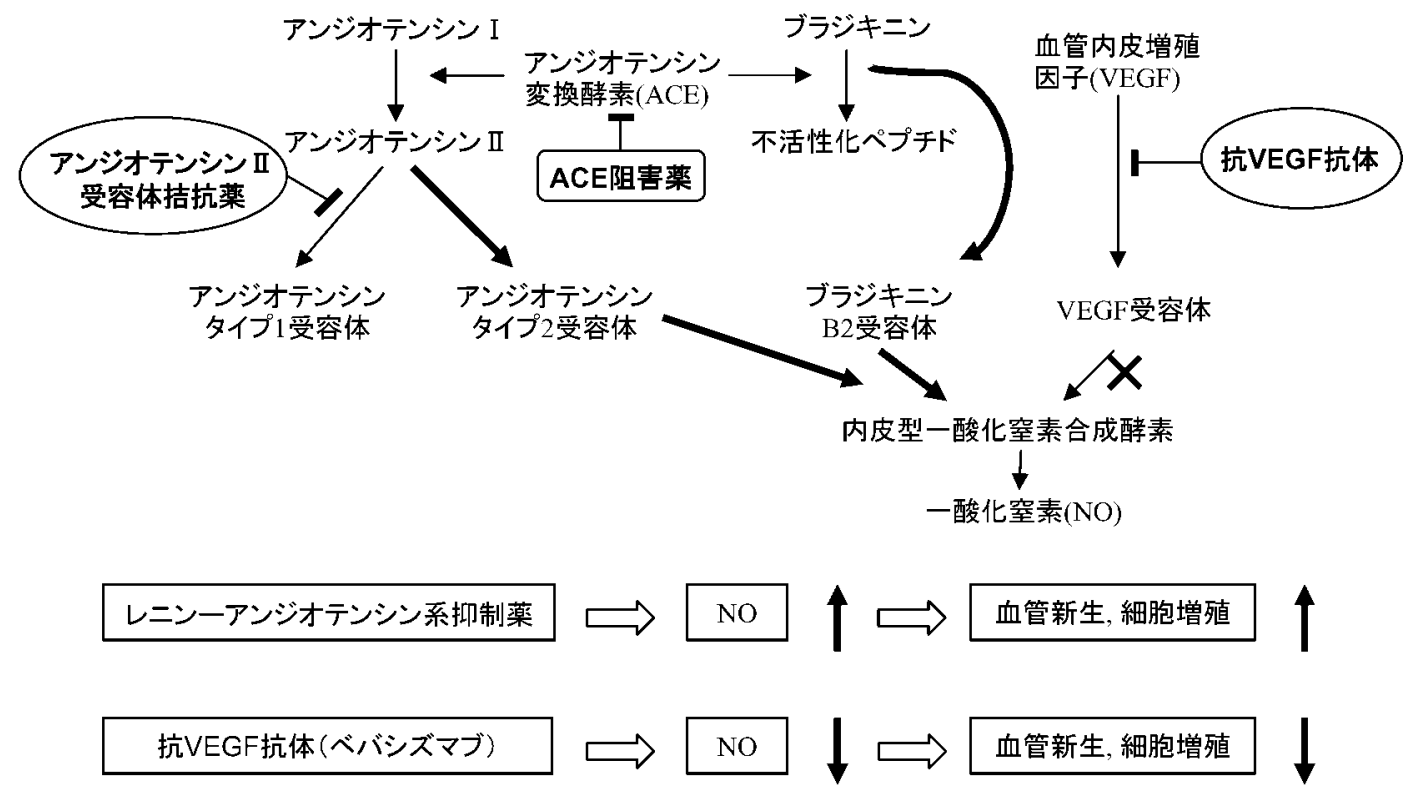

図 1 . ベバシズマブおよびレニンーアンジオテンシン系抑制薬の 一酸化窒素を介した作用機序 
(RECIST)基準に基づいて，医師が評価した判定を利用 した . 効果の解析は治療期間中の最良総合効果を評価す ることによって実施した .

\section{4. 倫理的配慮}

本研究は, 京都大学大学院医学研究科・医学部医の倫 理委員会の承認を得て行った(承認番号 E-436: がん化 学療法時の副作用関連データの評価と数理統計モデル解 析に関する研究).

\section{5. 統計学的処理}

データは平均値士 標準偏差として表した．また，パラ メトリックな検定には， Studentの対応のあるおよび対 応のないt検定を適用して行った .ノンパラメトリック な検定は， Fisher の正確確率検定および Wilcoxon の順 位和検定を用いて実施した，有意水準は危険率 $5 \%$ 未満 とした .

\section{結果}

\section{1. 患者背景および化学療法の投与量}

まず，RA 系抑制薬投与群と非投与群の患者背景を比 較した(表 1) . 投与群における3 症例のうち , アンジオ テンシン変換酵素(以下, ACE と略す)阻害薬(カプトプ リル)を服用していた患者は 1症例であり，治療開始前 から服用していた . 残り 2 症例はアンジオテンシン॥ (以下, AT II と略す)受容体拮抗薬を服用していた . 2 症 例とも薬斉はカンデサルタンシレキセチルであり，一方

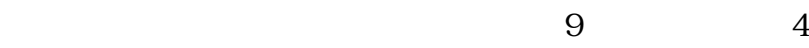
コース目からの服用であった . また，非投与群のうち， $\mathrm{RA}$ 系抑制薬以外の降圧薬を服用していた患者は 5 症例
であり, 降圧薬の種類は Ca拮抗薬，遮断薬および利 尿薬であった .

投与群での患者の年齢は, 非投与群と比して有意に高 いことが示されたものの $(p<0.05)$, 乥れ以外の項目は両 群間で差が認められなかった . また，既施行レジメン数 は投与群で少ない傾向が示された .

一方, 図 2 は, 施行された抗がん斉の投与量を両群間 で比較した結果を示す.ベバシズマブの投与量および mFOLFOX 6/FOLFIRI 療法の標準投与量に対する施行投 与量の割合は, 両群間で有意な差は認められなかった .

2. 高血圧および蛋白尿に及ぼす $\boldsymbol{R A}$ 系抑制薬の影響 次に, RA 系抑制薬併用によるべバシズマブの副作用 マネジメントについて調べた . 図 3 に示すように，非投 与群の収縮期圧および拡張期圧は, 治療前と比べ治療後 は有意に高值を示した $(p<0.01)$. 一方, 投与群の血圧 は, 非投与群よりも大きく変動したが, 収縮期圧および 拡張期圧とも治療前後で有意な差は認められなかった . また，収縮期圧および拡張期圧を両群で比較した結果， 治療前後のいずれの時期においても有意な差は示されな かった .

高血圧および蛋白尿の重症度を表 2 に示した . 高血圧 の重症度は，投与群が非投与群と比較して有意に高かっ た $(p<0.05)$.また, 非投与群で Grade 2 の副作用が 3 症 例に認められたが, 光のうち 2 症例は降圧薬を服用して いた患者であった。一方，蛋白尿に及ぼす影響を調査し た結果, 蛋白尿は, 治療後, いずれの群でも同程度に認 められ，すべてが Grade 1 と軽微な副作用であった .

3. RA 系抑制薬の抗腫瘍効果に及ぼす影響

最後に, RA 系抑制薬のベバシズマブの抗腫瘍効果に

表 1 . 患者背景

\begin{tabular}{|c|c|c|c|c|}
\hline & & \multicolumn{2}{|c|}{ R A 系抑 制薬 } & \multirow{2}{*}{$p$ 值 } \\
\hline & & 非投与群 & 投 与 群 & \\
\hline 症 例 数 & & 23 & 3 & \\
\hline 男性/女性 & & $10 / 13$ & $2 / 1$ & $0.580^{\mathrm{a}}$ \\
\hline 年 齢中央値（範囲） & & $59(40 \sim 80)$ & $73(71 \sim 83)$ & $0.013^{\mathrm{b}}$ \\
\hline \multirow[t]{2}{*}{ Performance status } & 0 & 22 & 3 & \multirow{2}{*}{$1.000^{\mathrm{a}}$} \\
\hline & 1 & 1 & 0 & \\
\hline 原 発 部 位（結 腸／直 腸 ） & & $14 / 9$ & $3 / 0$ & $0.529^{\mathrm{a}}$ \\
\hline \multirow[t]{3}{*}{ 臨 床 病 期 } & III A & 4 & 0 & \\
\hline & III B & 3 & 0 & $0.279^{\mathrm{b}}$ \\
\hline & IV & 16 & 3 & \\
\hline 既 施 行レジメン数 \pm S.D. & & $3.0 \pm 2.1$ & $1.0 \pm 0.7$ & $0.137^{\mathrm{b}}$ \\
\hline $\begin{array}{l}\text { ベバシズマブ併 用レジメン } \\
\text { (mFOLFOX6/FOLFIRI) }\end{array}$ & & $10 / 13$ & $1 / 2$ & $1.000^{\mathrm{a}}$ \\
\hline 治療コース数中 央 值 (範 囲) & & $6(3 \sim 19)$ & $9(4 \sim 14)$ & $0.285^{b}$ \\
\hline
\end{tabular}

${ }^{a}$ Fisher's exact probability test. ${ }^{b}$ Wilcoxon rank-sum test. 

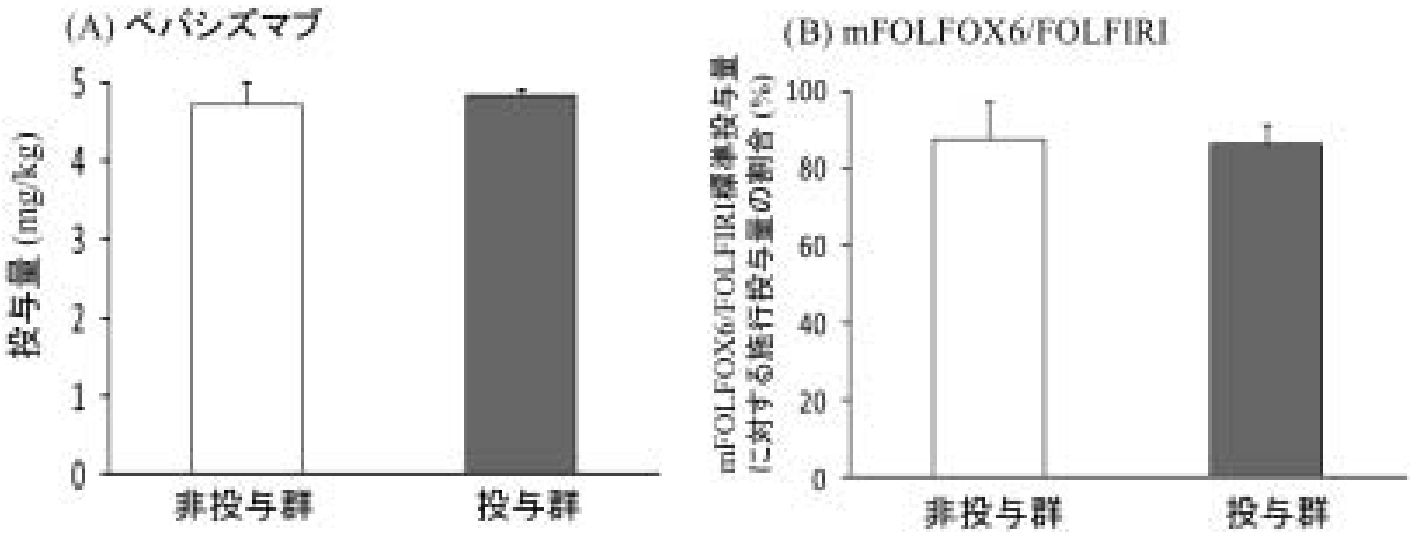

図 2 .ベバシズマブおよび mFOLFOX 6/FOFIRI の投与量

コース数 : 非投与群 $(n=147)$, 投与群 $(n=27)$. データは平均值 \pm 標準偏差を示す.

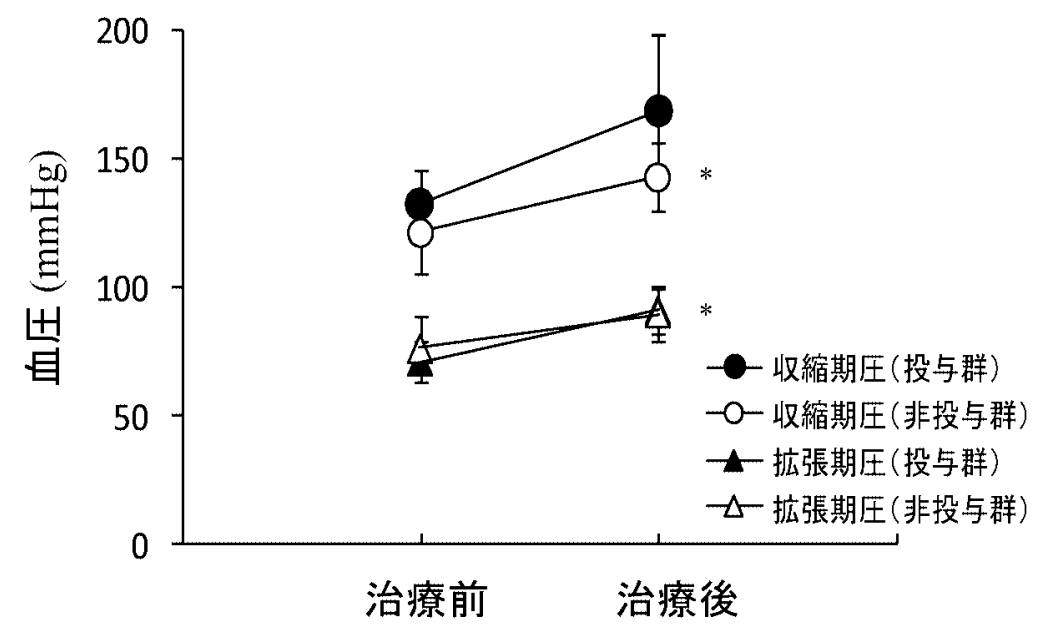

図 3 . ベバシズマブによる血圧変動に及ぼすレニン-アンジオテンシン系 抑制薬の影響

症例数 : 非投与群 $(n=23)$, 投与群 $(n=3)$. データは平均值 \pm 標準偏 差を示す . ${ }^{*} p<0.01$ vs 治療前(非投与群) : Student' s paired t-test.

表 2 . 高血圧および蛋白尿の重症度に及ぼすレニンーアンジオテンシン系 抑制薬の影響

\begin{tabular}{|c|c|c|c|c|c|c|}
\hline \multirow{2}{*}{ 重 症 度 } & \multicolumn{2}{|c|}{ 高血圧 } & \multirow{2}{*}{$p$ 值 ${ }^{*}$} & \multicolumn{2}{|c|}{ 蛋白尿 } & \multirow{2}{*}{$p$ 值 " } \\
\hline & 非投与群 & 投与群 & & 非投与群 & 投与群 & \\
\hline Grade 0 & 19 & 1 & \multirow{4}{*}{0.034} & 19 & 1 & \multirow{4}{*}{0.062} \\
\hline Grade 1 & 1 & 0 & & 4 & 2 & \\
\hline Grade 2 & 3 & 1 & & 0 & 0 & \\
\hline Grade 3 & 0 & 1 & & 0 & 0 & \\
\hline
\end{tabular}

症例数：非投与群 $(n=23)$, 投与群 $(n=3)$. 重症度の判定: Common Terminology Criteria for Adverse Events v3.0 (CTCAE v3.0). "Wilcoxon rank-sum test. 


\begin{tabular}{cccc} 
表 3 . 抗腫痬効果に及ぼすレニンーアンジオテンシン系抑制薬の影響 \\
\hline 最良総合効果 & 非投与群 & 投与群 & $p$ 值 \\
\hline CR & 0 & 0 & \\
PR & 6 & 0 & 0.002 \\
SD & 16 & 0 & \\
PD & 1 & 3 & \\
\hline
\end{tabular}

症例数 : 非投与群 $(n=23)$, 投与群 $(n=3)$. CR : complete response. PR : partial response. SD : stable disease. PD : progressive disease. ${ }^{*}$ Wilcoxon rank-sum test.

及ぼす影響を調べた(表 3). 非投与群では，完全奏効(以 下，CR と略す)と評価された症例は認められなかった が, 弚の多くは, 部分奏効(以下, PR と略す)あるいは 安定(以下, SD と略す)と判定された。進行(以下, PD と略す)と判定された症例は, 1 症例のみであった .し かし, 投与群の症例は，すべて $\mathrm{PD}(3$ 症例)と判定された . したがって，抗腫瘍効果は投与群が非投与群と比較して 有意に低かった $(p<0.01)$ ．また，病勢をコントロールで きた症例 $(\mathrm{CR}+\mathrm{PR}+\mathrm{SD})$ は , 非投与群 22 症例，投与群 0 症例であり，有意な差か認められた $(p=0.002)$.

\section{考察}

本研究では，RA 系抑制薬のベバシズマブに及ぼす影 響を明らかにするため，副作用のマネジメントおよび抗 腫瘍効果について調査した .ベバシズマブにより惹起さ れる副作用として，RA 系抑制薬と関連する高血圧およ び蛋白尿を調べたところ，投与群は非投与群と比較して 有意な差は示されなかったが血圧上昇の程度は大きく， その重症度では有意に高いことが明らかになった，重症 度に有意な差か認められた理由は，高血圧に関する重症 度の分類基準の一つに，2種類以上の薬物治療または以 前よりも強い治療を要することが含まれており，従来よ り高血圧の治療を行っていた患者は重症度が高く判定さ れるためと考えられた .一方, 蛋白尿の発現には有意な 差は認められず，光の副作用も Grade 1 と軽微であるこ とが判明した．したがって，本研究ではRA 系抑制薬の 明確な副作用の治療効果は認められなかった .また ,デー タには示していないが, 非投与群のうち，RA 系抑制薬 以外の降圧薬を服用していた症例は，降圧薬を服用して いない症例と比べて, 血圧上昇および重症度は大きい傾 向が観察された . 高血圧の既往を有する患者には血圧の マネジメントがより必要であると考えられる．今回，蛋 白尿がいずれの群も許容される副作用であったことか ら，一次選択薬として安定した降圧作用を期待できる RA 系抑制薬以外の降圧薬を考慮することも必要と考え られる．降圧薬の選択については，適正なマネジメント を実践するためにも，さらなる検討が必要であると推察
された .

一方 , ベバシズマブの臨床効果を評価したところ，非 投与群は，ほとんどがPR およびSD の判定であり，病 勢を制御できたと評価できる．しかし，投与群の効果判 定は，す心゙てPDであった．したがって，抗腫瘍効果お よび病勢コントロールは，投与群が非投与群と比較して 有意に低いことが明らかになった。したがって，本研究 結果は，RA 系抑制薬の使用によってベバシズマブの抗 腫瘍効果が減弱する可能性が示唆された，比較した患者 背景に関して, 投与群の症例は非投与群に比べ高齢で あった．しかし，投与群においてPSの低下は認められ ず，また，特記すべき藏器障害を合併した症例はなかっ たことから，全身状態は良好であったと考えられる．ま た，投与群は非投与群と比べ化学療法歴も少なく，病態 はむしろ安定していたものと推察できる.さらに，進行 大腸がんの高齢患者(年齢中央值 76 歳 : 70 82歳)を対 象に, FOLFOX および FOLFIRI の効果と忍容性につい て検討した報告では，PR 27.6\%，SD 37.9\% および生存 期間中央值 21 力月と，若年者を含む他の研究結果と同 等であることが示されている ${ }^{17)}$. 产のため, 高齢であっ たことがPD の要因に影響しているとは考えにくい．

Cameron らの糖尿病ラットを用いた検討において, リ シノプリルの投与が筋肉の毛細血管を著明に増加させる ことを明らかにし，ACE 阻害薬が血管新生促進因子と して機能することを示唆している ${ }^{18)}$.この知見は，がん 領域に関する研究ではないものの，本臨床結果を一部支 持するものと考えられる . 実際に , 鍛冶園らはベバシズ マブ投与患者に対する降圧薬選択のためのフローチャー 卜を作成したが，彼らの報告を受けて ACE 阻害薬を選 択基準から除外している ${ }^{199}$.

ACE 阻害薬およびAT II 受容体拮抗薬とは同等の藏器 保護作用を発揮し，产の効果の一部は血管新生に基づい ていると考えられている．血管新生および細胞増殖に とってNO は促進因子である.ACE 阻害薬はブラジキ ニンの産生を亢進させるが，このブラジキニン効果は NOの合成促進をもたらす ${ }^{10}$. AT II 受容体拮抗薬も，選 択的アンジオテンシンタイプ1受容体の遮断が, 間接的 なアンジオテンシンタイプ 2 受容体の活性化を介して , 
ブラジキニンの産生を引き起こし，結果的にNO の合成 促進をもたらす ${ }^{16)}$ これに対して ,ベバシズマブはVEGF の阻害から NO 合成経路は阻害され, NO の産生は低下 する.このRA 系抑制薬とベバシズマブの NO 合成に対 する相反する効果(図 1)が，ベバシズマブとRA 系抑制 薬との併用による効果減弱の生物学的メカニズムの一つ と推察される。また，ACE 阻害薬あるいはAT II 受容体 拮抗薬の服用によるNO 産生によって, 腫瘍細胞を取り 巻く血管新生は促進されることが予想される . 兴のよう な状況下においては，NO に関する産生促進あるいは抑 制という相互作用とともに, 新生された血管の数がRA 系抑制薬を服用していた症例においてはより多く密に なっているためにベバシズマブの効果が充分に認められ ない可能性も考えられる .

ベバシズマブは大腸がん以外のがん種でも注目されて いる有望な薬剂であり，乥の効果を最大限に引き出すた めにも，本研究で明らかにされたベバシズマブと RA 系 抑制薬との併用による抗腫瘍効果減弱の可能性に関する 知見は極めて重要な意味を持つと考えられる．今後，十 分なサンプルサイズを持つ前向き，あるいは後ろ向きな 臨床研究を実施すること，ならびにベバシズマブの薬理 作用と RA 系抑制薬との関連性を基礎的に究明すること などによって, 本研究結果のさらなる検証が必要と考え られる。

謝辞 本研究は日本病院薬剂師会がん専門薬剤師研修事業 において取り組んだ個人課題であり，本研修を受け入れてい ただきました京都大学医学部附属病院，ならびに本研修参加 にご支援いただきました社会保険京都病院のみなさまに，心 より感謝申し上げます．

\section{引用文献}

1) L. B. Saltz, S. Clarke, E. Díaz-Rubio, W. Scheithauer, A. Figer, R. Wong, S. Koski, M. Lichinitser, T-S. Y ang, F. Rivera, F. Couture, F. Sirzen, J. Cassidy, Bevacizumab in combination with oxaliplatin-based chemotherapy as firstline therapy in metastatic colorectal cancer: A randomized phaselll study, J. Clin. Oncol ., 26, 2013-3110 (2008).

2) C.S. Fuchs, J. marshall, J. Barrueco, Randomized, controlled trial of irinotecan plus infusional, bolus, or oral fluoropyrimidines in first-line treatment of metastatic colorectal cancer: Updated results from the BICC-C study, J. Clin. Oncol ., 26, 689-690 (2008).

3) R. K. Jain, Tumor angiogenesis and accessibility : role of vascular endothelial growth factor, Semin. Oncol., 29, 3-9 (2002).

4) J.A. Nagy, E. V asile, D. Feng, C. Sundberg, L.F. Brown, M. J. Detmar, J.A . Lawitts, L. Benjamin, X. Tan, E.J. Manseau, A.M. Dvorak, H.F. Dvorak, Vascular permeability factor/ vascular endothelial growth factor induces lymphangiogenesis as well as angiogenesis, J. Exp. Med., 196, 1497-1506
(2002).

5) G.P. Pidgeon, M.P. Barr, J.H. Harmey, D.A. Foley, D.J. Bouchier-Hayes, V ascular endothelial growth factor (VEGF) upregulates BCL-2 and inhibits apoptosis in human and murine mammary adenocarcinoma cells, Br. J. Cancer, $\mathbf{8 5}$, 273-278 (2001).

6) D.I. Gabrilovich, T. Ishida, S. Nadaf, J.E. Ohm, D.P. Carbone, Antibodies to vascular endothelial growth factor enhance the efficacy of cancer immunotherapy by improving endogenous dendritic cell function, Clin. Cancer. Res., 5, 2963-2970 (1999).

7) S. Kliche, J. Waltenberger, VEGF receptor signaling and endothelial function, IUBMB Life, 52, 61-66 (2001).

8) D. M. Dudzinski, J. Igarashi, D. Greif, T. Michel, The reguIation and pharmacology of endothelial nitric oxide synthase, Annu. Rev. Pharmacol. Toxicol ., 46, 235-276 (2005).

9) D.E. Golan, A.H. Tashijian 編 ““ハーバード大学テキスト 病態生理に基づく臨床薬理学”, 清野裕日本語版監修, メ ディカル・サイエンス・インターナショナル , 2006, pp. 344-345.

10) D.C. Sane, L. Anton, K.B. Brosnihan, Angiogenic growth factors and hypertension, Angiogenesis, 7, 193-201 (2004).

11) M.S. Gordon, D. Cunningham, Managing patients treated with bevacizumab combination therapy, Oncology, 69, 2533 (2005).

12) A. Hara, T. Wada, K. Furuichi, N. Sakai, H. Kawachi, F. Shimizu, M. Shibuya, K. Matsushima, H. Yokoyama, K. Egashira, S. Kaneko, Blockade of VEGF accelerates proteinuria, via decrease in nephrin expression in rat crescentic glomerulonephritis, Kidney Int ., 69, 1986-1995 (2006).

13) F. Kabbinavar, A. Shah, Guidelines for the management of side effects of bevacizumab in patients with colorectal cancer, Cancer Ther., 6, 327-340 (2008).

14) M. Dincer, Angiotensin-converting enzyme inhibitors for bevacizumab-induced hypertension, Ann. Pharmacother., 40, 2278-2279 (2006).

15) A. Pande, J. Lombardo, E. Spangenthal, M. Javle, Hypertension secondary to anti-angiogenic therapy : experience with bevacizumab, Anticancer Res., 27, 3465-3470 (2007).

16) 屋山勝俊 , 岡本博 , アンジオテンシンタイプ 2 受容体を 介した血管弛緩機構，YAKUGAKU ZASSHI，127，13571367 (2007).

17) R. Berardi, T. Saladino, D. Mari, R.R. Silva, M. Scartozzi, L. Verdecchia, A. Onofri, S. Cascinu, Elderly patients with advanced colorectal cancer : Tolerability and activity of che motherapy, Tumori, 91, 463-466 (2005).

18) N.E. Cameron, M.A . Cotter, S. Robertson, A ngiotensin converting enzyme inhibition prevents development of muscle and nerve dysfunction and stimulates angiogenesis in streptozotocin-diabetic rats, Diabetologia, 35, 12-18 (1992).

19）鍛冶園誠，谷口仁司，岩井加菜子, 藤原伀子, 松永尚, 小川喜通，千堂年昭，山下晴弘，市場泰全，ベバシズマ ブ使用時における副作用自己管理表の作成による薬剤誘 導性の高血圧発現症例入の対応，日本病院薬剂師会杂隹 誌 , 44, 1401-1404 (2008). 